\title{
PERANAN TEKNOLOGI TERHADAP PERJUANGAN HAK JUAL-BELI MASYARAKAT JAWA BARAT PADA MASA PANDEMI
}

\author{
Gaudia Sweta Kumara, Muhammad Ilman Karimurrahman, Ramadhyan Priyo Sembodo, \\ \& Silvano Leonard Winata \\ Institut Teknologi Bandung \\ Email: gaudiaskmr@gmail.com
}

\begin{abstract}
Abstrak
Sejak zaman dahulu, manusia telah melakukan kegiatan jual-beli untuk memenuhi kebutuhan hidupnya. Berkerumun dan berkumpul untuk melakukan transaksi jual-beli menjadi suatu rutinitas dan bagian dari gaya hidup. Pasar konvensional dan mal menjadi tempat yang tidak sepi akan pengunjung. Namun, pandemi COVID-19 pada akhir tahun 2019 membuat pemerintah Indonesia melakukan pembatasan kegiatan sosial. Masyarakat dilarang untuk berkegiatan sosial dalam skala besar sehingga dilarang untuk berkerumun di tempat ramai. Pusat perbelanjaan pun sebagian besar ditutup dan membatasi jumlah pengunjungnya. Kondisi pandemi membuat masyarakat secara terpaksa harus mengadaptasi gaya hidup baru yang mengurangi kontak langsung dengan orang lain. Adanya kemajuan pada teknologi berbasis internet memberikan peluang pada masyarakat untuk menghadapi pembatasan sosial tersebut. Kini pandemi COVID-19 telah berlangsung selama dua tahun dan masih belum diketahui kapan akan berkahir. Masyarakat telah menciptakan gaya hidup baru, menyesuaikan diri dengan kondisi pandemi. Perlaku baru pun muncul ketika melakukan kegiatan jual-beli. Penelitian ini bertujuan untuk mengukur efektivitas teknologi berbasis daring terhadap kegiatan jual-beli masyarakat pada masa pandemic. Pengumpulan data pada penelitian ini dilakukan melalui observasi dan pembagian kuesioner secara daring. Melalui penelitian ini, diharapkan diketahuinya sikap masyarakat pada kegiatan jual-beli dalam masa pandemic yang telah berlangsung selama dua tahun dan diperolehnya data rill pada lapangan.
\end{abstract}

Kata Kunci: Jual-Beli, Teknologi, Daring, Masyarakat, Perilaku

\begin{abstract}
Since ancient times, humans have been doing buying and selling activities to meet their needs. Crowding and gathering to make buying and selling transactions becomes a routine and part of the lifestyle. Conventional markets and malls become places that are not empty of visitors. However, the COVID-19 pandemic at the end of 2019 led the Indonesian government to restrict social activities. People are forbidden to do social activities on a large scale so it is forbidden to crowd in crowded places. Shopping malls were mostly closed and limited the number of visitors. Pandemic conditions make people forced to adapt a new lifestyle that reduces direct contact with others. Advances in internet-based technology provide opportunities for people to face these social restrictions. Now the COVID-19 pandemic has been going on for two years and it is still unknown when it will be eradicated. Society has created a new lifestyle, adjusting to pandemic conditions. New equipment also appeared when doing buying and selling activities. This research aims to measure the effectiveness of online-based technology against people's buying and selling activities during pandemics. The data collection in this study was conducted through observation and online questionnaire sharing. Through this research, it is expected that the public's attitude to buying and selling activities in the pandemic period that has lasted for two years and the acquisition of rill data in the field.
\end{abstract}

Keywords: Buying and Selling, Technology, Online, Community, Behavior

\section{PENDAHULUAN}

Sejak zaman dahulu, manusia telah melakukan kegiatan jual-beli untuk memenuhi kebutuhan hidupnya. Dimulai dari ditemukannya sistem barter hingga sistem uang yang digunakan hingga sekarang, manusia dapat memenuhi kebutuhan hidup sehari-hari dengan 
melakukan pertukaran barang antara satu sama lain. Kegiatan jual-beli menjadi pilar utama dalam perputaran roda masyarakat yang merupakan penentu nasib keberlangsung hidup manusia. Adanya perubahan dalam aktivitas jual-beli memberikan tanda pada kondisi ekonomi masyarakat. Perputaran roda ekonomi yang baik ditandai dengan tingginya angka aktivitas jual-beli masyarakat.

Pasar merupakan sarana untuk melakukan kegiatan ekonomi paling umum dan mendasar. Keberadaan pasar menjadi suatu hal yang sangat vital untuk pergerakan roda ekonomi karena merupakan sarana paling efektif dalam menjalankan kegiatan jual-beli. Kondisi pasar memengaruhi pergerakan roda ekonomi. Ramainya aktivitas jual-beli masyarakat di pasar memberikan tanda akan kondisi ekonomi masyarakat. Pasar yang ramai akan pengunjung memberikan tanda akan kondisi pasar yang baik.

Memasuki era digital, keberadaan pasar konvensional dan pusat perbelanjaan menjadi tempat yang tidak pernah sepi akan pengunjung yang hendak melakukan kegiatan jual-beli. Hal ini disebabkan oleh fungsi pasar yang bertambah sehingga tidak hanya sebagai sarana berkegiatan jual-beli, namun juga sebagai sarana rekreasi. Masyarakat yang berkunjung ke pusat perbelanjaan cenderung tidak hanya bertujuan untuk melakukan kegiatan ekonomi saja, namun untuk berkegiatan sosial juga. Pusat perbelanjaan yang dijadikan sebagai tempat untuk berkumpul dan beraktivitas bersama menjadikannya sebagai tempat yang selalu ramai dan selalu didatangi orang.

Posisi Jawa Barat yang dekat dengan ibu kota Indonesia membuatnya menjadi wilayah sering dilalui oleh banyak orang. Keadaan tersebut membuat pasarpasar di Jawa Barat memiliki kondisi ekonomi yang baik karena ramainya pengunjung. Namun, Jawa Barat memiliki wilayah dengan dua karakteristik yang berbeda, yakni masyarakat urban dan masyarakat tradisional. Masyarakat urban di Jawa Barat sebagian besar tinggal di wilayah Jabodetabek dan Bandung Raya sedangkan masyarakat tradisional berada di daerah pedasaan yang tersisa. Perbedaan identitas tersebut mengakibatkan munculnya perbedaan kondisi ekonomi pada dua wilayah tersebut. Hal tersebut diakibatkan oleh perbedaan kebutuhan pada masyarakat masing-masing wilayah. Wilayah yang ditempati masyarakat urban cenderung ramai dan padat akan penduduk sehingga membuat kebutuhan yang harus dipenuhi pun menjadi beragam. Sedangkan pada wilayah yang ditempati masyarakat tradisional tidak memiliki kebutuhan yang beragam-ragam seperti pada wilayah masyarakat urban. Perbedaan kondisi pasar pada kedua wilayah tersebut mengakibatkan adanya perbedaan pada perilaku dalam aktivitas jual-beli masyarakat Jawa Barat.

Pandemi COVID-19 yang terjadi pada akhir tahun 2019 memberikan dampak pada seluruh dunia. Pemerintah di berbagai negara, termasuk Indonesia terpaksa melakukan isolasi dan pembatasan kegiatan sosial. Masyarakat diperintah untuk membatasi kontaklangsung terhadap orang lain sehingga hanya diperbolehkan untuk melakukan kegiatan sosial dalam skala kecil saja. Akses menuju tempat ramai dibatasi dan sebagian besar ditutup. Pembatasan sosial tersebut membuat masyarakat harus bergantung pada teknologi untuk tetap terhubung dengan satu sama lain. Secara terpaksa, masyarakat harus mulai hidup berdampingan dengan teknologi berbasis internet yang terkadang masih terlihat asing untuk beberapa kalangan (Nurgiansah, 2020). Ketidaktahuan masyarakat akan teknologi tersebut 
membuat terputusnya hubungan sosial antara satu sama lain.

Pembatasan sosial yang diperintahkan oleh pemerintah memberikan dampak terhadap pergerakan roda ekonomi masyarakat. Melalui pembatasan akses terhadap pasar dan pusat perbelanjaan, angka aktivitas jualbeli masyarakat mengalami penurunan. Keberadaan pasar daring dipandang sebagai solusi dalam penyelesaian masalah jual-beli masyarakat dalam masa pandemi, karena tidak melanggar aturan pembatasan sosial pemerintah. Dalam waktu yang dekat, pasar digital menjadi ramai akan pengguna karena dianggap sebagai sarana alternatif untuk melakukan kegiatan jual-beli selama masa pandemi.

Pada tahun 2021, pandemi telah berlangsung selama dua tahun dan belum memberikan tanda akan berakhir. Masyarakat telah mengadapatasikan gaya hidup baru di mana berbagai macam kegiatan dijalankan secara daring. Meskipun pembatasan sosial telah dikurangi dan akses menuju pusat perbelanjaan telah dibuka, namun sebagian masyarakat masih memilih untuk menggunakan pasar daring. Selang waktu dua tahun, membuat pasar daring memberikan pengaruh terhadap kehidupan masyarakat. Karena itu, patut dipertanyakan pengaruh teknologi dalam kehidupan masyarakat dalam berkegiatan ekonomi selama masa pandemi. Oleh karena itu, melalui penelitian ini, penulis meneliti efektivitas pasar daring dalam keberlangsungan kegiatan jual-beli masyarakat Jawa Barat.

Berdasarkan latar belakang yang telah dipaparkan di atas, maka dapat dirumuskan beberapa poin rumusan masasalah sebagai berikut: bagaimana pasar daring membantu keberlangsungan aktivitas jual-beli masyarakat Jawa Barat? bagaimana tanggapan pelaku ekonomi di Jawa Barat terhadap penggunaan pasar daring setelah pandemi berlangsung selama dua tahun? dan bagaiaman kondisi ekonomi masyarakat Jawa Barat setelah masa pandemi berlangsung selama dua tahun?

Berdasarkan rumusan masalah yang ada, maka tujuan penelitian adalah untuk mengetahui dampak pasar daring pada keberlangsungan aktivitas jual-beli masyarakat Jawa Barat, untuk mengetahui tanggapan pelaku ekonomi di Jawa Barat terhadap penggunaan pasar daring setelah pandemic berlangsung selama dua tahun, dan untuk mengetahui kondisi ekonomi masyarakat Jawa Barat setelah masa pandemicberlangsung selama dua tahun.

Adapun manfaat penelitian ini adalah sebagai sarana edukasi masyarakat mengenai pengaruh pasar daring terhadap kegiatan jual-beli di Jawa Barat setelah pembatasan sosial masa pandemi Covid-19 berlangsung selama dua tahun dan sebagai acuan mengenai tanggapan masyarakat Jawa Barat terhadap keberadaan pasar daring setelah pembatasan sosial masa pandemi Covid-19 berlangsung selama dua tahun.

\section{METODE PENELITIAN}

Metodologi pengumpulan data pada penelitian ini menggunakan survei dan kuesioner untuk data kuantitatif serta studi dokumen untuk data kualitatif. Survei dan kuesioner dilakukan dengan pengisian form secara daring melalui gawai. Sedangkan studi dokumen dilakukan dengan pencarian artikel yang dapat mendukung penelitian. Metode kuantitatif yang digunakan pada penlitian ini adalah metode regresi dengan menggunakan variabel kepuasan masyarakat Jawa Barat terhadap keberadaan pasar daring selama masa pandemi Covid-19 berlangsung. Frekuensi dan efektivitas pemakaian menjadi faktor penentu dalam menentukan kepuasan masyarakat terhadap pasar daring. 
Metode kualitatif yang dipakai adalah metode fenomenologi. Fenomena yang diambil adalah berupa adanya pembatasan sosial selama Covid-19 berlangsung dan aspek subjektifnya berupa kepuasan masyarakat Jawa Barat terhadap keberadaan pasar daring. Perubahan perilaku masyarakat yang dianalisis adalah perilaku yang terbentuk setelah pembatasan sosial yang terjadi akibat pandemi berlangsung selama dua tahun.

\section{HASIL PENELITIAN DAN PEMBAHASAN Hasil Penelitian \\ Manusia Sebagai Makluk Ekonomi}

Manusia tidak hanya disebut sebagai makhluk sosial, tetapi juga sebagai makhluk ekonomi atau homo economicus. Melansir jurnal Homo Economicus oleh B. Herry Priyono (Nurgiansah, 2021), istilah tersebut berasal dari Adam Smith, seorang ekonom Inggris yang mencetuskan sistem ekonomi politik pertama. Pada dasarnya, manusia disebut sebagai makhluk ekonomi karena selalu berupaya memenuhi kebutuhan hidupnya sesuai dengan ilmu dan prinsip ekonomi. Dalam pemenuhan kebutuhan hidupnya untuk mencapai kesejahteraan hidup dan kepuasan hidup, manusia akan selalu mempertimbangkan pengorbanan yang harus dilakukan. Dengan mengetahui pengorbanan dan hasil yang dikeluarkan, manusia akan mengetahui apakah pengorbanan tersebut sepadan atau tidak. Tindakan-tindakan seperti itulah yang menjadikan manusia sebagai makhluk ekonomi.

Dilansir dari kumparan.com, berikut adalah karakteristik manusia sebagai makhluk ekonomi:

1. Melakukan tindakan yang bersifat rasional.

2. Keputusan yang diambil sesuai dengan tujuan.

3. Pemenuhan kebutuhan berfokus kepada diri sendiri.
4. Memiliki rasa tidak pernah puas.

5. Mempunyai banyak kebutuhan dan keinginan.

6. Tindakan ekonomi dilakukan dengan cara efisien.

7. Aktivitas yang dilakukan lekat dengan preferensi pribadi.

Sementara itu, kebutuhan manusia didasari atas keiginannya yang merupakan sesuatu yang sifatnya lebih luas dan juga tidak terbatas. Kebutuhan dan keinginan manusia beragam atas kondisi yang dihadapinya. Dilansir dari ekonomi.blog.unisbank.ac.id dan kompas.com, berikut adalah faktor yang memengaruhi kebutuhan dan keinginan manusia:

1. Jenis kelamin dan usia.

2. Lingkungan.

3. Tingkat pendidikan.

4. Kemajuan ilmu pengetahuan dan teknologi.

5. Status sosial.

6. Tingkat pendapatan.

7. Perbedaan selera

\section{Latar Belakang Kondisi Ekonomi Jawa Barat}

Jawa Barat merupakan salah satu provinsi di Indonesia yang terletak di Pulau Jawa dengan Ibu Kota Bandung. Wilayah Provinsi Jawa Barat berbatasan dengan Provinsi Banten, Provinsi Jawa Tengah, dan DKI Jakarta. Provinsi Jawa Barat didirikan pada tanggal 4 Juli 1950 berdasarkan Undang-Undang No. 11 Tahun 1950 yang meliputi wilayah Banten. Namun, pada November 2000, Provinsi Jawa Barat mengalami pemekaran sehingga memunculkan Provinsi Banten.

Pada tahun 2019 jumlah penduduk Jawa Barat tercata sebanyak 49,32 juta jiwa, menjadikannya sebagai provinsi terbesar di Indonesia dalam hal jumlah penduduk. Masyarakat Jawa Barat dikenal sebagai masyarakat yang religuis dengan 
kekayaan warisan budaya dan nilai-nilai luhur tradisional, serta memiliki perilaku sosial yang berfalsafah pada silih asih, silih asah, silih asuh, yang secara harfiah berarti saling mengasihi, saling memberi pengetahuan, dan saling mengasuh diantara warga masyarakat.

Masyarakat Jawa Barat terdiri atas dua identitas berkarakter konstras, yakni masyarakat urban yang Sebagian besar tinggal di wilayah Jabodetabek serta Bandung Raya dan masyarakat tradisional yang hidup di daerah pedesaan. Perbedaan identitas tersebut mengakibatkan masyarakat Jawa Barat memiliki kebutuhan yang berbeda-beda pada masing-masing wilayah. Namun, meskipun demikian, masyarakat Jawa Barat memiliki sifat terbuka akan budaya baru menjadikan masyarakatn yang dinamis dan cenderung selalu mengikuti mode atau gaya yang sedang beredar. Kecenderungan tersebut membuat masyarakat Jawa Barat memiliki sifat konsumtif terhadap produk yang baru dan ramai sedang beredar.

Dalam komposisi penduduk yang bekerja, Jawa Barat memiliki penduduk dengan usia produktif (15-64 tahun) mencapai 33,23 juta orang dan usia nonproduktif sebanyak 15,45 juta dengan rasio ketergantungannya sebesar 46,51. Pekerja di Jawa Barat didominasi oleh lulusan SD, yakni mencapai 40,23 persen dan presentase angkatan kerja terhadap penduduk usia kerja yang tamat SD sebesar 63,19 persen. Sedangkan untuk pekerja lulusan perguruan tinggi mencapai 11,5 persen dan persentase angkatan kerja terhadap usia kerja yang tamat perguruan tinggi sebesar 80,63 persen.

Indonesia yang merupakan negara agraris membuat sektor pertanian menempati posisi penting untuk roda pergerekan ekonomi masyarakatnya. Hal ini dapat ditunjukkan dari banyaknya penduduk atau tenaga kerja yag hidup bekerja dalam sektor pertanian. Sebagai negara agraris, Indonesia dianugerahi kekayaan alam yang melimpah ditambah posisinya yang berada di garis khatulistiwa membuatnya memiliki iklim tropis dan bercurah hujan yang tinggi. Jawa Barat yang memiliki sumber daya manusia yang melimpah membuatnya mampu bersaing dalam berbagai sektor perkeonomian selain pertanian, seperti industri manufaktur, pertambangan, perairan dan kelautan, serta pariwisata.

Sektor pertanian di Jawa Barat memegang peran penting dalam perekonomian negara. Hal dikarenakan Jawa Barat dikenal sebagai lumbung padi nasional yang membuatnya menjadi salah satu provinsi penyumbang produk pangan tertinggi Indonesia. Pada tahun 2019, tercata luas panen padi sebesar 1,5 juta hektar dengan produksi sebesar 9 juga ton, sedangkan produksi beras tercata sebesar 5 juta ton. Selain pertanian, Jawa Barat memiliki peluang bisnis perkebunan dan berperan cukup besar pada pengembangan sektor pertanian. Pada tahun 2019, produksi buah-buahan terbesar di Jawa Barat adalah pisang, yaitu sebesar 12 juta kwintal. Sementara itu, produksi sayursayuran di Jawa Barat didominasi oleh tomat, yakni sebesar 2,8 juta kwintal.

Sumber daya manusia yang melimpah dan posisinya yang strategis membuat Jawa Barat memiliki daya saing dalam sektor industru dan manufaktur (Nurgiansah, 2018). Adanya kawasan industri terbesar di Indonesia terletak di Karawang membuat Jawa Barat memiliki akses terhadap fasilitas dengan teknologi tercanggih dan terlengkap dalam hal teknologi industrinya. Hal tersebut membuat Jawa Barat mampu memberikan mengkosentrasikan manufakturnya pada berbagai bidang, seperti elektronik, industri kulit, tekstil, furnitur, pengolahan makanan, dan migas.

Indonesia yang merupakan negeri kepulauan memberikan potensi dalam 
sektor perikanan dan kelautan pada berbagai wilayahnya. Posisi Jawa Barat yang berhadapan dengan dua sisi lautan Pulau Jawa memberikan potensi yang sangat kuat dalam sektor perikanan dan kelautan. Pada tahun 2019, produksi perikanan tangkap di laut sebanyak 248 ribu ton dan di perariran umum sebanyak 15 ribu ton.

Suku beragam dan pesona alam yang indah membuat Indonesia memiliki potensi yang besar dalam sektor pariwisata. Didukung dengan posisinya yang strategis dan penampakan alam yang beragam membuat Jawa Barat menjadi destinasi tujuan wisata dari berbagai wilayah, baik domestik, maupun mancanegara. Kota Bandung yang dijuluki Paris van Java menjadi salah satu daya tarik utama Jawa Barat.

\section{Pandemi Covid-19 dan Pengaruhnya Terhadap Kegiatan Jual-Beli}

Virus corona atau Coronovirus disease 2019 (disingkat Covid-19) pertama kali ditemukan di Wuhan, Cina pada akhir tahun 2019. Wabah Covid-19 ditetapkan sebagai pandemi pada awal tahun 2020. Virus yang mampu menyebar melalui udara dan kontak langsung membuat penyebaran virus terjadi dengan mudah. Covid-19 memiliki gejala yang terlihat seperti flu biasa, menjadikannya sulit untuk dideteksi. Hal tersebut membuat berbagai negara di dunia termasuk Indonesia, terpaksa melakukan isolasi dan melakukan pembatasan sosial pada masyarakatnya. Akses menuju area publik pun ditutup oleh pemerintah dan hanya membuka fasilitas penting saja, seperti rumah sakit. Keadaan yang melarang adanya kontak langsung dengan orang lain membuat masyarakat Indonesia terpaksa untuk menjalankan rutinitas dengan bantuan teknologi berbasis internet.

Pada Provinsi Jawa Barat, pembatasan sosial dilakukan sesuai dengan perintah dari pemerintah pusat. Masyarakat diminta untuk melakukan isolasi mandiri dan dilarang untuk melakukan kontak dengan orang lain. Dengan akses menuju area publik, seperti pasar dan mal ditutup, membuat kegiatan jual-beli sulit dilakukan. Secara terpaksa, masyarakat Jawa Barat harus bergantung dengan komunikasi daring untuk menjalankanaktivitas jual-beli.

Hal tersebut mengakibatkan berbagai jenis usaha yang mengharuskan kontak langsung dan berada di area publik, seperti restoran, terpaksa berhenti beroperasi menjelang masa pandemi berlangsung. Selain itu, kebutuhan akses internet yang mendadak meningkat membuatnya tidak dapat tersebar ke seluruh bagian masyarakat Jawa Barat. Dengan terbatasnya media untuk bertransaksi, kegiatan jual- beli masyarakat Jawa Barat pun terhembat menjelang masa pandemi Covid-19.

\section{Pasar Konvensional, Pasar Modern, dan Pasar Daring}

Dilansir dari ekonomi.bunghatta.ac.id, Pasar kovensional atau tradisional merupakan pasar di mana dalam kegiatannya atau proses transaksinya masih dilakukan secara tradisional, yaitu penjual dan pembeli bertemu untuk melakukan tawar-menawar harga suatu barang atau jasa. Pasar tradisional merupakan bagian dari pembentukan aktivitas perkotaan dengan berbagai macam fungsi (Jano, 2006). Ditegaskan juga apabila pasar konvensional bukan hanya tempat yang dipergunakan untuk kegiatan jual- beli, tetapi pasar tradisional era hubungannya karena berkaitan terhadap konsep kehidupan, interaksi sosial, dan budaya, serta menjadi sarana rekreasi yang lebih penting dari sekedar untuk bertransaksi (Pamardhi,1997).

Umumnya jenis pasar konvensional 
berada di lokasi terbuka dan produk yang dijual adalah kebutuhan pokok manusia, yaitu pangan dan papan. Pasar konvensional dibangun dan dikelola oleh pemerintah daerah, BUMN, BUMD, atau pihak swasta. Tempat berjualan di pasar ini biasanya terdiri dari kios-kios atau gerai, los, dan lapangan terbuka. Sayangnya, kebanyakan jenis pasar ini terlihat kumuh karena kebersihannya kurang terjaga.

Pasar modern adalah pasar yang dikelola dengan manajemen modern, umumnya terdapat di Kawasan perkotaan, sebagai penyedia barang dan jasa dengan mutu dan pelayanan yang baik kepada konsumen (Sinaga, 2006). Menurut para ahli, hal yang membedakan pasar konvensional dengan pasar modern adalah bahwa di pasar modern, penjual dan pembeli tidak melakukan transaksi secara lnagsung.

Pembeli hanyalah melihat label harga dari suatu produk yang ingin dibeli. Kemudian transaksi akan dilayani dengan mandiri oleh kasir atau pramuniaga. Berbagai produk yang diperjualbelikan di dalam pasar ini adalah produk yang sudah teruji kualitasnya dan harganya yang sudah ditentukan. Keberdaan pasar modern cenderung menciptakan kesenjangan ekonomi karena perbedaan harga yang diberikan dibandingkan dengan yang didapat dari pasar konvensional.

Memasuki era digital, munculnya sebuah tuntutan agar setiap kegiatan harus dilakukan secara cepat. Akibatnya rutinitas padat menjadi hal yang umum dimiliki masyarakat. Untuk berbagai kalangan masyarkat, kegiatan jual-beli yang dilakukan secara langsung di pasar konvensional dan modern dianggap menyibukkan dan menghambat pekerjaan sehari-hari. Keberadaan pasar daring menjadi solusi dalam masalah tersebut. Pasar daring adalah pasar yang mempertemukan penjual dan pembelinya secara daring melalui media dengan akses internet di mana transaksi dilakukan tanpa adanya kontak langsung. Melalui pasar daring kegiatan jual-beli dapat dilakukan kapan saja dan di mana saja selama ada gawai dengan akses internet.

\section{Pembahasan}

Kuesioner kami awali dengan pertanyaan umur dan asal daerah responden untuk mengetahui distribusi responden.
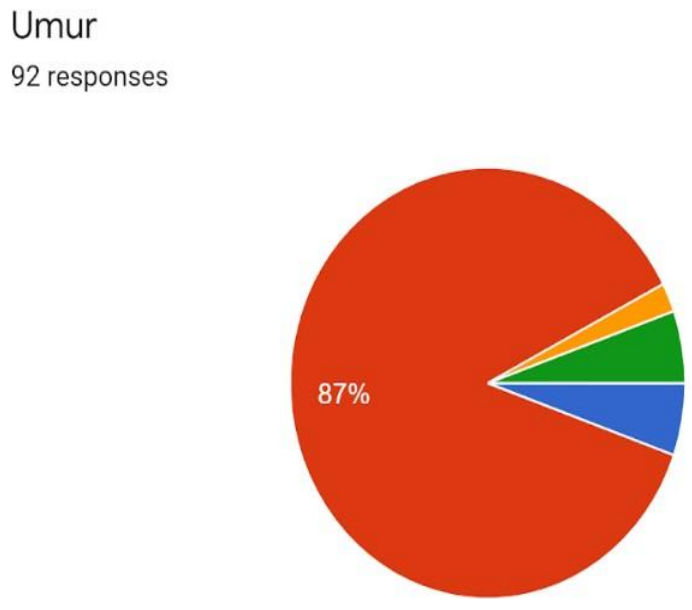

$\leq 17$ tahun

18-25 tahun

26-33 tahun

34-59 tahun

$\geq 60$ tahun

Gambar 1. Persebaran Umur Responden 


\section{Asal Daerah}

92 responses

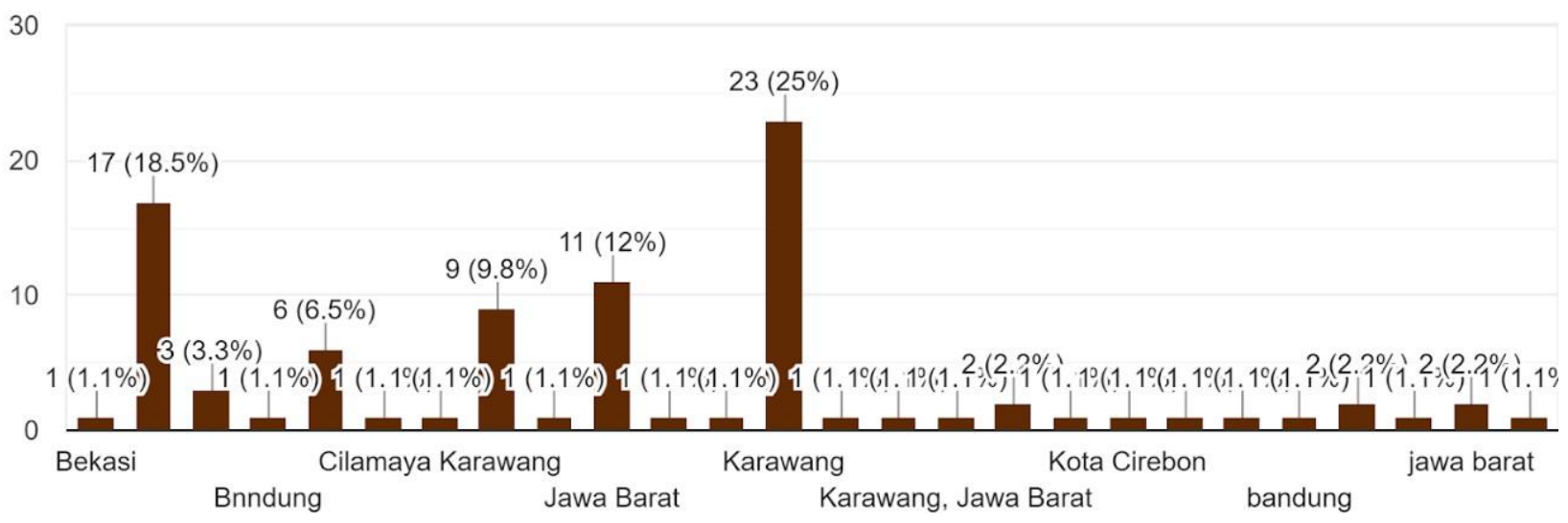

Gambar 2. Persebaran Asal Daerah Responden

Berdasarkan gambar 1 dan gambar 2 di atas, dapat dilihat bahwa mayoritas responden atau sebanyak $87 \%$ berumur 18-25 tahun, diikuti dengan 17 tahun ke bawah dan 34-59 tahun. Dapat dilihat pula bahwa responden tersebar dari beberapa daerah Jawa Barat. Responden terbanyak berasal dari daerah Karawang, diikuti oleh Bandung, Depok, Bogor, dan daerah Jawa Barat lainnya, seperti Bekasi, Cirebon, Subang, Tambaksari, dan lainnya.

Kami juga memberikan pertanyaan untuk mengetahu jenjang pendidikan responden.

\footnotetext{
Jenjang Pendidikan

92 responses
}
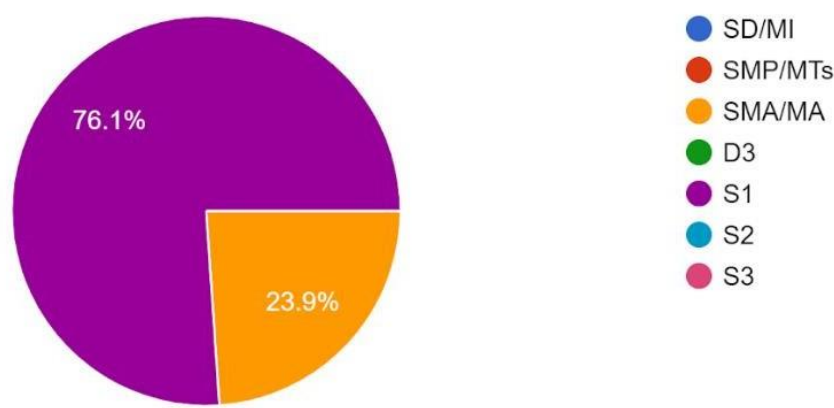

Gambar 3. Persebaran Jenjang Pendidikan Responden

Mayoritas responden atau sebesar $76,1 \%$ merupakan mahasiswa S1, sedangkan sisanya merupakan siswa SMA. Selanjutnya, kami menanyakan beberapa pertanyaan untuk mengetahui aktivitas jual-beli online responden selama pandemi. Pertanyaan pertama yang kami tanyakan adalah sejak kapan responden mulai aktif berkegiatan jual-beli online. 
Sejak kapan Anda mulai aktif berkegiatan jual-beli online?

90 responses

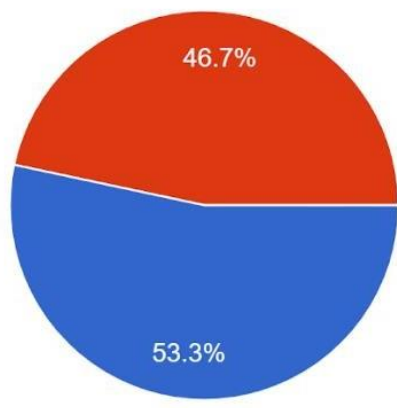

Sebelum pandemik ( $\leq$ akhir 2019)

Saat pandemi berlangsung

Gambar 4. Persentase Pertanyaan 1

Sebanyak 48 dari 92 responden atau 53,3\% menjawab bahwa mereka sudah mulai aktif berkegiatan jual-beli online sejak sebelum pandemi. Sisanya, sebanyak 44 dari 92 responden atau $46,7 \%$ menjawab bahwa mereka baru mulai aktif berkegiatan jual-beli online saat pandemi. Pertanyaan kedua yang kami tanyakan adalah seberapa sering responden berjualan online sebelum pandemi.

Platform apa yang biasanya Anda gunakan untuk berjualan online?

92 responses

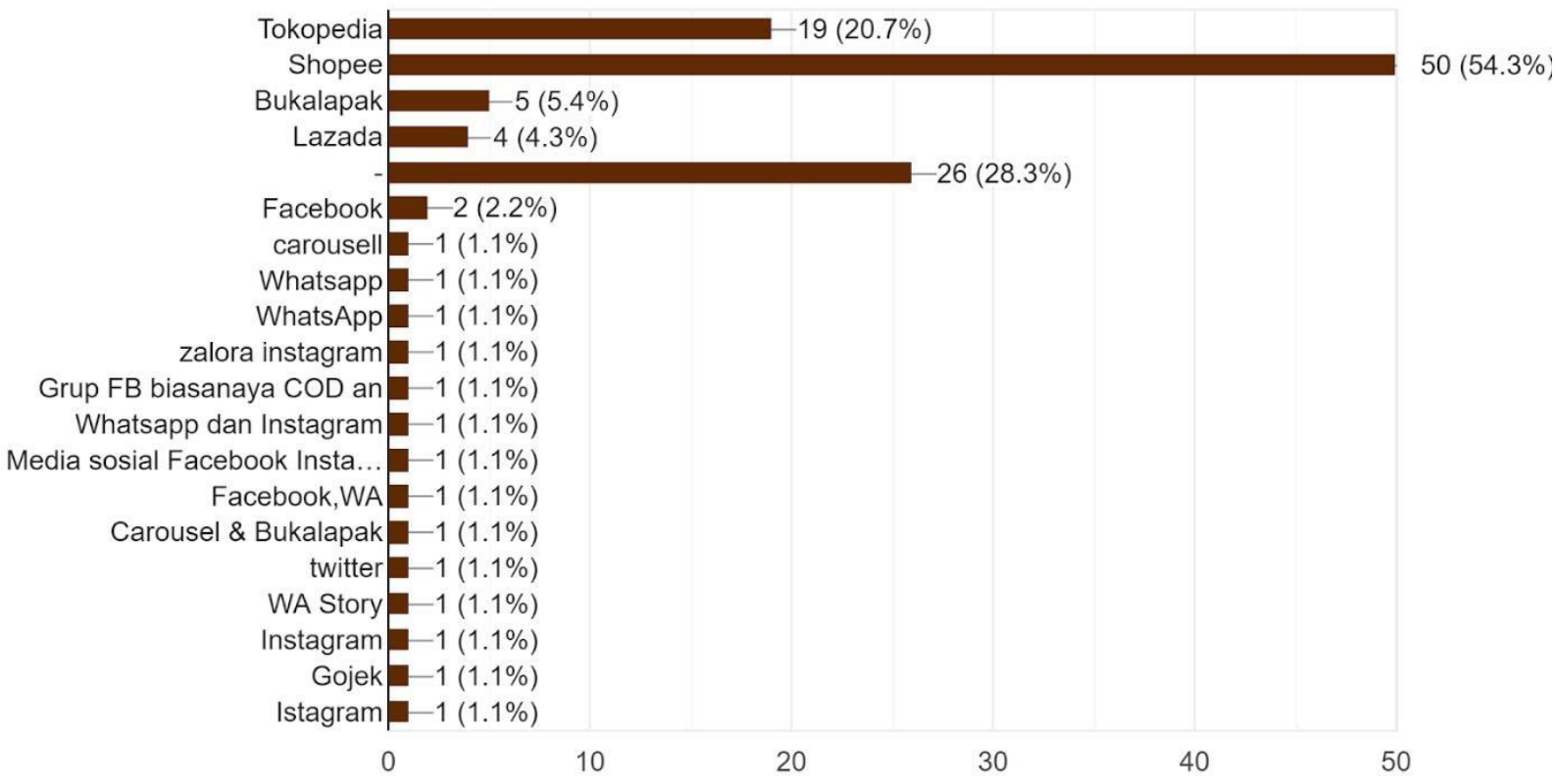

Gambar 5. Persentase Pertanyaan 2

Sebanyak 40 dari 92 responden atau $43.5 \%$ menjawab 1-tidak pernah, 13 dari responden atau $14.1 \%$ menjawab 2 -jarang, 22 dari 92 responden atau $23.9 \%$ menjawab 3-cukup sering, 12 dari 92 responden atau $13 \%$ menjawab 4-sering, dan 5 dari 92 responden atau $5.4 \%$ menjawab selalu. Pertanyaan ketiga yang 


\begin{abstract}
kami tanyakan adalah seberapa sering pandemi. responden berjualan online selama

Seberapa seringnya Anda berjualan online selama masa pandemi?

92 responses
\end{abstract}

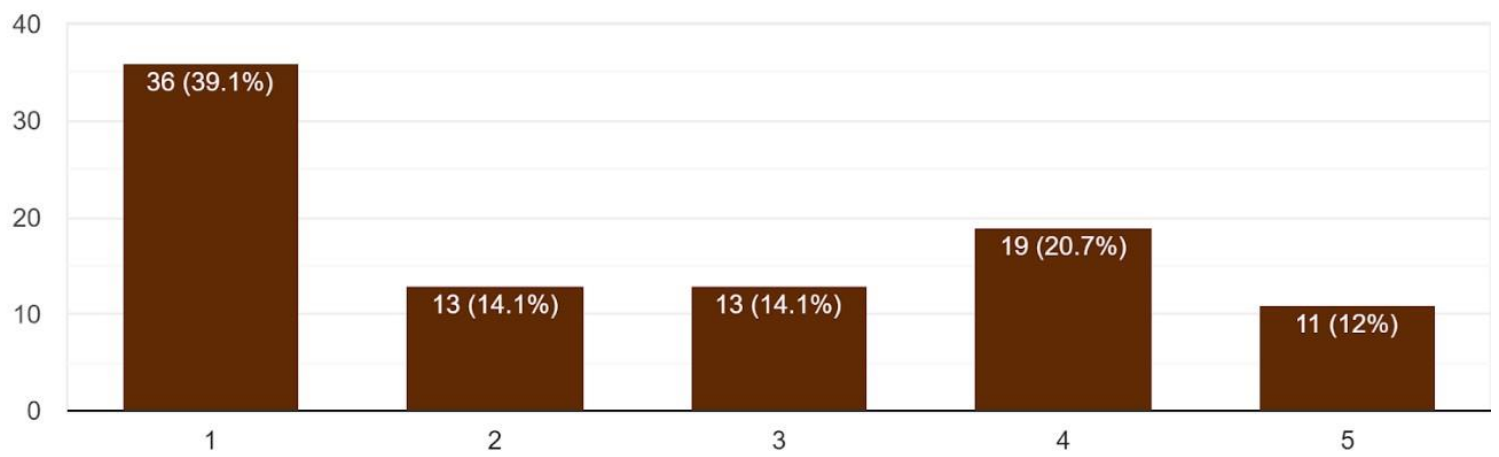

Gambar 6. Persentase Pertanyaan 3

Sebanyak 36 dari 92 responden atau $39.1 \%$ menjawab 1-tidak pernah, 13 dari responden atau $14.1 \%$ menjawab 2-jarang, 13 dari 92 responden atau 14.1\% menjawab 3-cukup sering, 19 dari 92 responden atau $20.7 \%$ menjawab 4 -sering, dan 11 dari 92 responden atau 12\% menjawab selalu.

Berdasarkan dua diagram yang kami dapatkan yang membandingkan frekuensi berjualan online responden sebelum dan selama pandemi, dapat dilihat bahwa frekuensi berjualan online responden meningkat. Terbukti dari berkurangnya jawaban 1-tidak pernah, dan jawaban 4-sering meningkat. Pertanyaan keempat yang kami tanyakan adalah platform apa yang responden sering gunakan dalam berjualan online.

\title{
Seberapa seringnya Anda berjualan online sebelum masa pandemi?
} 92 responses

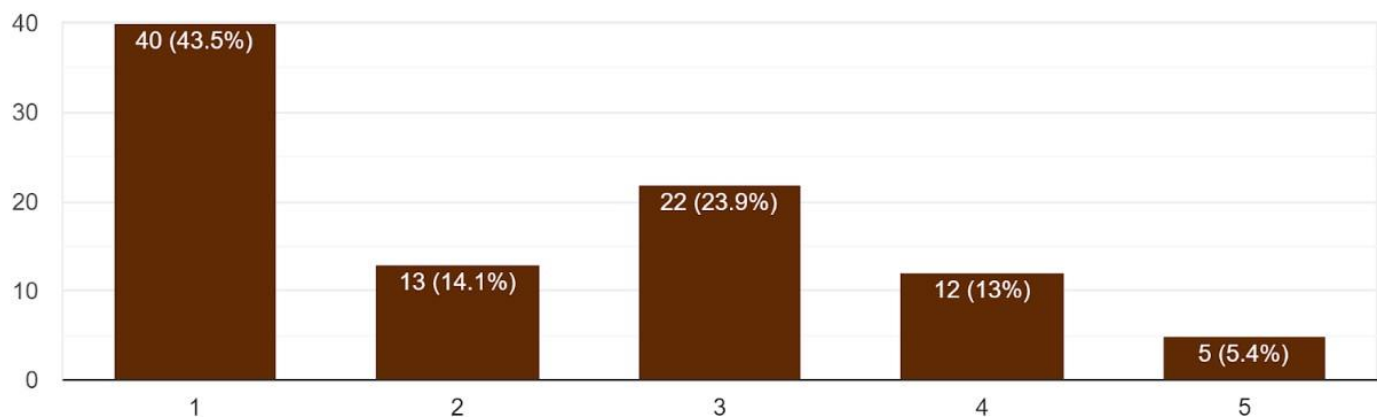

Gambar 7. Persentase Pertanyaan 4

Mayoritas responden atau sebesar 54.3\% menggunakan platform Shopee, 19 dari 92 responden atau $20.7 \%$ menggunakan Tokopedia, 5 dari 92 responden atau $5.4 \%$ menggunakan Bukalapak, 4 dari 92 responden atau 4.3\% menggunakan Lazada, dan sisanya menggunakan platform lain, seperti gojek, dan instagram. Pertanyaan kelima yang kami tanyakan adalah apakah platform tersebut memudahkan responden dalam berjualan online beserta alasannya. 
Apakah platform tersebut memudahkan Anda dalam berjualan online?

92 responses
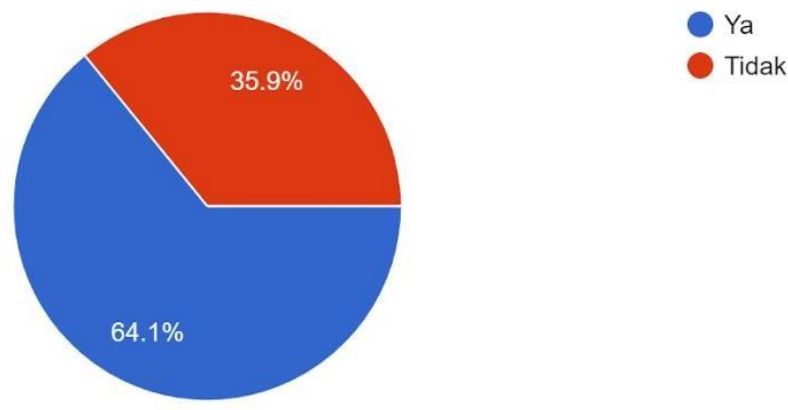

Gambar 8. Persentase Pertanyaan 5

Mayoritas responden atau 64.1\% menjawab ya atau merasa dimudahkan, sedangkan sisanya menjawab tidak. Alasan yang kami dapatkan cukup beragam, seperti praktis, lebih mudah tampilannya, bisa menjual banyak barang, dikenal banyak orang, mudah dan cepat di pembayaran, fiturnya lengkap dan mudah dipahami. Pertanyaan keenam yang kami tanyakan adalah apakah responden memiliki keluhan dalam berjualan online beserta alasannya.

Apakah Anda memiliki keluhan dalam berjualan online?

92 responses

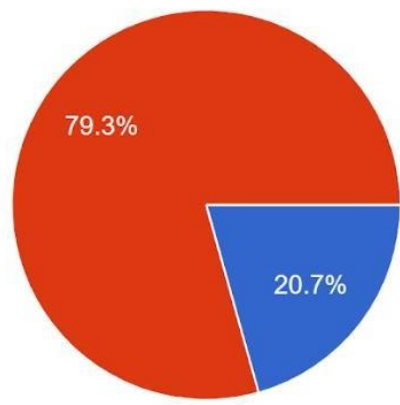

Gambar 9. Persentase Pertanyaan 6

Mayoritas responden atau 79.3\% menjawab tidak memiliki keluhan, sedangkan sisanya mejawab ya. Alasan yang kami dapatkan juga cukup beragam, seperti "Banyak penipuan", "Banyak saingannya", "Kadang sepi", "Kurangnya pengikut", "Keluhan dari konsumen karena kesalahannya sendiri", "Konsumen membatalkan pesanan tiba-tiba", "Kurirnya lama", "Server down", "Waktu tayang produk hanya 24 jam", "Kadang barang rusak saat pengiriman".

Pertanyaan ketujuh yang kami tanyakan adalah seberapa sering responden berbelanja online sebelum pandemi. 
Seberapa seringnya Anda berbelanja online sebelum masa pandemi?
92 responses

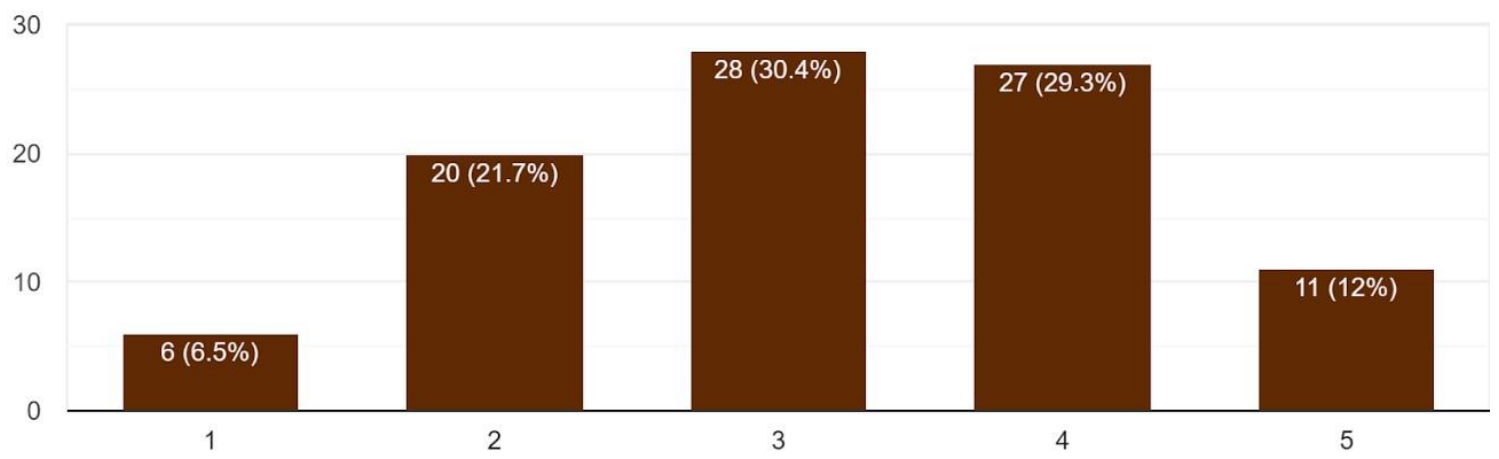

Gambar 10. Persentase Pertanyaan 7

Sebanyak 6 dari 92 responden atau 6.5\% menjawab 1-tidak pernah, 20 dari responden atau $21.7 \%$ menjawab 2-jarang, 28 dari 92 responden atau 30.4\% menjawab 3-cukup sering, 27 dari 92 responden atau $29.3 \%$ menjawab 4 -sering, dan 11 dari 92 responden atau 12\% menjawab selalu. Pertanyaan kedelapan yang kami tanyakan adalah seberapa sering responden berbelanja online selama pandemi.

\section{Seberapa seringnya Anda berbelanja online selama masa pandemi? \\ 92 responses}

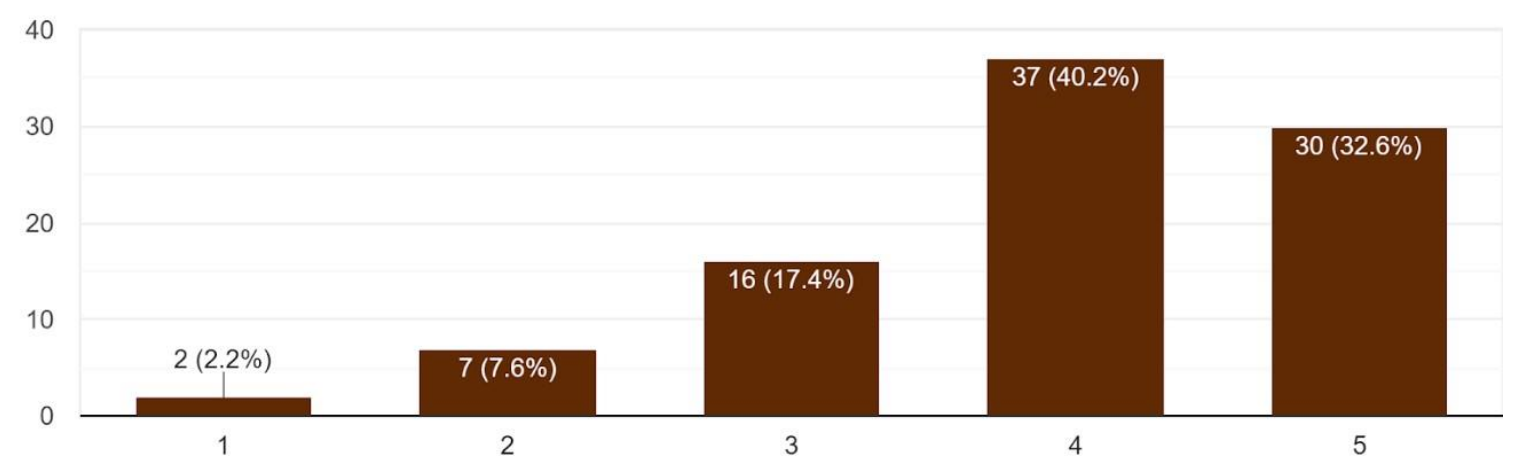

Gambar 11. Persentase Pertanyaan 8

Sebanyak 2 dari 92 responden atau $2.2 \%$ menjawab 1-tidak pernah, 7 dari responden atau $7.6 \%$ menjawab 2-jarang, 16 dari 92 responden atau $17.4 \%$ menjawab 3-cukup sering, 37 dari 92 responden atau 40.2\% menjawab 4sering, dan 30 dari 92 responden atau $32.6 \%$ menjawab selalu. Berdasarkan dua diagram yang kami dapatkan yang membandingkan frekuensi berbelanja online responden sebelum dan selama pandemi, dapat dilihat bahwa frekuensi berbelanja online responden meningkat. Pertanyaan kesembilan yang kami tanyakan adalah platform apa yang responden gunakan untuk berbelanja online. 
Platform apa yang biasanya Anda gunakan untuk berbelanja online?

92 responses

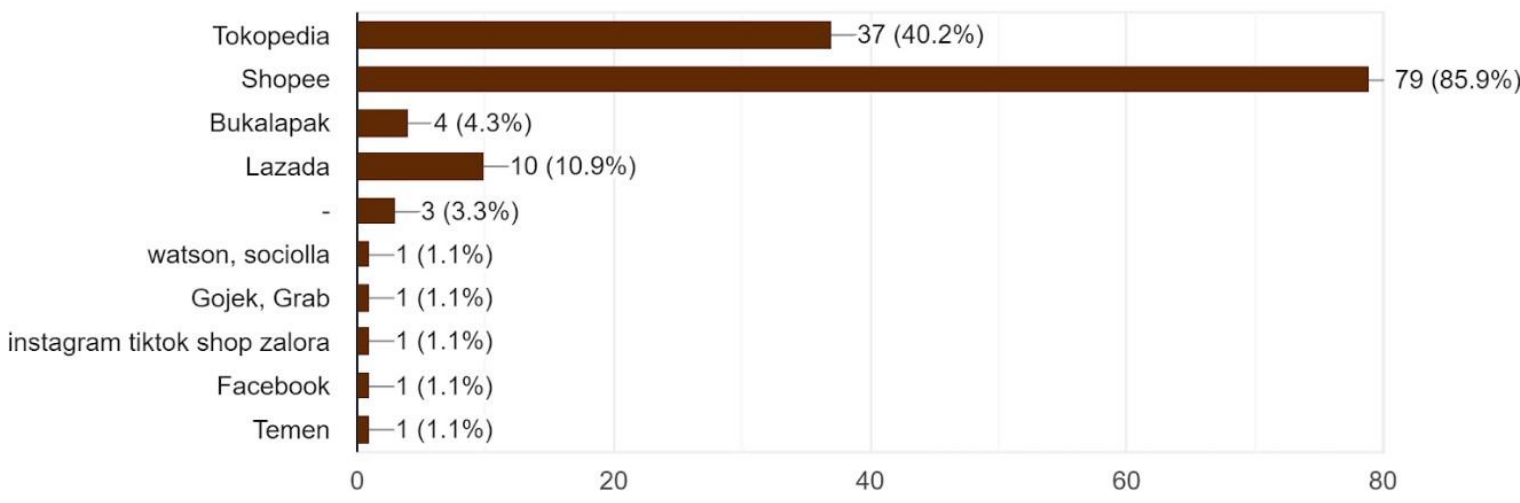

Gambar 12. Persentase Pertanyaan 9

Mayoritas responden atau sebesar 79 responden menggunakan platform Shopee, 37 responden menggunakan Tokopedia, 4 responden menggunakan Bukalapak, 10 responden menggunakan Lazada, dan sisanya menggunakan platform lain, seperti gojek, instagram, dan instagram. Pertanyaan kesepuluh yang kami tanyakan adalah apakah platform tersebut memudahkan responden dalam berbelanja online beserta alasannya.

\section{Apakah platform tersebut memudahkan Anda dalam berbelanja online? 92 responses}
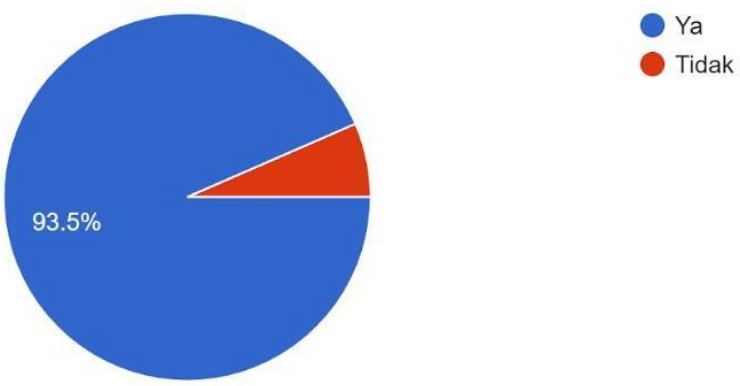

Gambar 13. Persentase Pertanyaan 10

Mayoritas responden atau 93.5\% menjawab ya atau merasa dimudahkan, sedangkan sisanya menjawab tidak. Alasan yang kami dapatkan cukup beragam, seperti tidak perlu keluar, gratis ongkir, harga lebih murah, alur jelas dan mudah dipahami, transaksi lebih mudah, pengiriman lebih mudah, barang lebih banyak, barangnya variatif dan lengkap, pembayaran lebih mudah, harga terjangkau, selalu mendapatkan apa yang dicari, banyak discount, mudah dalam menggunakan aplikasi, tampilannya menarik dan lebih banyak pilihan dan promo, mudah akses aplikasi, instan dan cepat. Pertanyaan kesebelas yang kami tanyakan adalah apakah responden memiliki keluhan dalam berbelanja online. 
Apakah Anda memiliki keluhan dalam berbelanja online?

92 responses
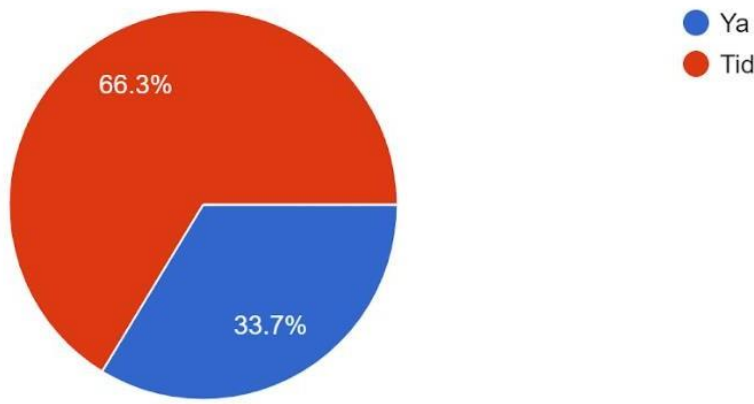

Tidak

Gambar 14. Persentase Pertanyaan 11

Mayoritas responden atau $66.3 \%$ menjawab tidak, sedangkan sisanya menjawab ya. Alasan yang kami dapatkan cukup beragam, seperti ada seller yang membuat kebijakannya sendiri sehingga mempersulit transaksi, aslinya tidak sesuai aplikasi, barang tidak sesuai pesanan, keluhan sering terjadi ketika cacat barang, barangnya lama datengnya, stok barang sudah habis dan pengiriman lama, terkadang pengirimannya agak lama, tidak sesuai dengan fotonya, barang tidak sesuai, masing-masing platform harganya bedabeda jadi susah cari yang paling murah. Pertanyaan terakhir yang kami tanyakan adalah bagaimana perubahan kondisi ekonomi responden selama pandemi.

\section{Bagaimana perubahan kondisi ekonomi Anda setelah pandemi berlangsung selama dua tahun? 92 responses}

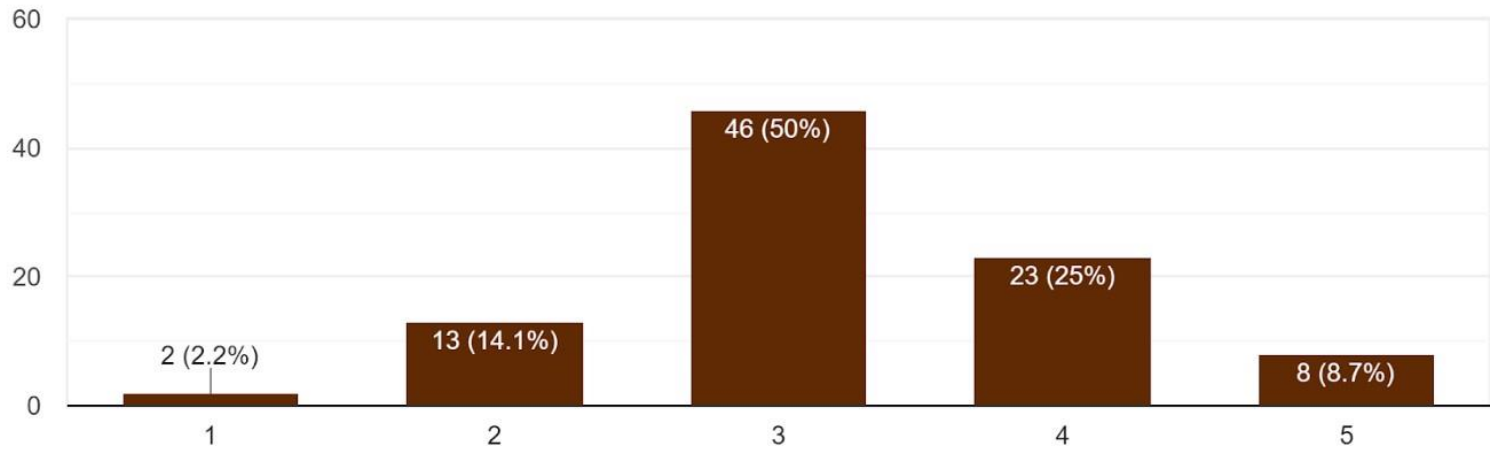

Gambar 15. Persentase Pertanyaan 12

Mayoritas responden atau sebesar $50 \%$ menjawab kondisi ekonomi stabil, $8,7 \%$ menjawab membaik, dan 2.2\% menjawab memburuk.

\section{KESIMPULAN}

Berdasarkan hasil penelitian yang sudah lakukan, pengguna pasar daring untuk aktivitas jual-beli bertambah, hal ini terbukti dengan sebanyak 46,7\% responden mulai aktif berkegiatan jual-beli daring. Sebanyak 43,5\% responden yang sebelum pandemi tidak pernah berjualan daring berubah menjadi 39,1\% yang tidak pernah berjualan daring selama pandemi. Selain itu, penggunaan pasar daring untuk berbelanja daring sangat terlihat perbedaannya, $6,5 \%$ responden yang 
sebelum pandemi tidak pernah berbelanja daring berubah menjadi $1,3 \%$ saja selama pandemi berlangsung, kemudian sebanyak $29,3 \%$ responden yang sebelum pandemi sering belanja daring berubah menjadi hampir dua kali lipatnya yaitu sebanyak $47,4 \%$ selama pandemi berlangsung, selain itu perubahan yang terlihat dengan jelas yaitu sebanyak $12 \%$ responden selalu berbelanja daring sebelum pandemi berubah menjadi lebih dari tiga kali lipatnya, yaitu sebanyak 38,5\% yang saat pandemi selalu menggunakan pasar daring untuk melakukan kegiatan berbelanja daring.

$\begin{array}{cll}\text { Penjual } & \text { pada pasar daring } \\ \text { kebanyakan } & \text { menyatakan } & \text { bahwa }\end{array}$
penggunaan pasar daring memudahkan dalam penjualan, karena dirasa lebih praktis dan mudah, tetapi para penjual pasar daring juga memiliki keluhan seperti kurangnya peminat, banyak saingan, dan beberapa keluhan yang menyangkut dengan ekspedisi seperti rusaknya produk saat pengiriman dan pengiriman yang lama.

Para pengguna pasar daring untuk berbelanja merasa bahwa penggunaan pasar daring dirasa lebih cepat, lebih murah, lebih mudah, barang variatif, dan keunggulan lainnya adalah tidak perlu keluar rumah pada saat pandemi, tetapi menurut konsumen terdapat kekurangan pada pasar daring seperti barang yang didapat berbeda dengan barang yang ada pada toko, pengiriman lama, dan sering terjadi kerusakan pada saat pengiriman barang. Terdapat $16,3 \%$ responden yang merasa kondisi ekonominya menjadi lebih buruk saat pandemi berlangsung, dan $33,7 \%$ responden merasa kondisi ekonominya menjadi lebih baik selama pandemi berlangsung, sedangkan 50\% responden tidak merasakan perubahan pada kondisi ekonomi baik sebelum dan selama pandemi berlangsung.

\section{DAFTAR PUSTAKA}

Aditya, Iip M. (2020). Karawang, Lumbung Padi yang Jadi Kawasan Industri Terkemuka. https://www.goodnewsfromindonesia.id/2020/11/25/karawang-lumbung-padiyang- jadi-kawasan-industri-terkemuka

Aninsi, Niken. (2021). Inilah Alasan Mengapa Indonesia Disebut sebagai Negara Agraris. https://katadata.co.id/safrezi/berita/61658d3d7db87/inilah-alasan-mengapaindonesia-disebut-sebagai-negara-agraris

Apa itu Sebenarnya Pandemi COVID-19? Ketahui juga Dampaknya di Indonesia. https://www.prudential.co.id/id/pulse/article/apa-itu-sebenarnya-pandemi-covid19- ketahui-juga-dampaknya-di-indonesia/

Apa yang Dimaksud Manusia sebagai Homo Economicus? Cek Penjelasannya berikut. https://ekonomi.blog.unisbank.ac.id/apa-yang-dimaksud-manusia-sebagai-homoeconomicus-cek-penjelasannya-berikut/\#

Fadli, Dr. Rizal. (2021). Begini Kronologi Lengkap Virus Corona Masuk Indonesia. https://www.halodoc.com/artikel/kronologi-lengkap-virus-corona-masuk-indonesia

Herlando, Dodi. (2020). Provinsi Jawa Barat dalam Angka. Bandung. BPS Provinsi Jawa Barat https://jabar.bps.go.id/

https://jabarprov.go.id/

https://jabartoday.com/profil-jawa-barat/

Ibnuismail, (2020). Pasar Modern: Pengertian, Ciri-ciri, Kelebihan dan Kekurangannya. https://accurate.id/ekonomi-keuangan/pasar-modern-adalah/

Mengapa Manusia Disebut Makhluk Ekonomi? Ini Penjelasannya. https://kumparan.com/berita-hari-ini/mengapa-manusia-disebut-makhluk-ekonomi- 
ini-penjelasannya-1v6VivKg6xW

Novrianti, Tri Vina. (2021). Dampak Pandemi COVID-19 terhadap Kondisi Sosial dan Ekonomi Pedagang Pasar Perumas Way Halim, Kota Bandar Lampung. http://repo.itera.ac.id/depan/submission/SB2106020024

Nuraini, Tantiya Nimas. (2020). Cerita Lengkap Asal Mula Munculnya Virus Corona di Indonesia. https://www.merdeka.com/trending/cerita-lengkap-asal-mulamunculnya-virus-corona-di-indonesia.html

Nurgiansah, T. H. (2018). Pengembangan Kesadaran Hukum Berlalu Lintas Siswa Melalui Model Pembelajaran Jurisprudensial Dalam Pendidikan Kewarganegaraan (Studi Kasus di SMK Bina Essa Kabupaten Bandung Barat Kelas X Administrasi Perkantoran). Tesis. Repository Universitas Pendidikan Indonesia, Oktober. http://ieeeauthorcenter.ieee.org/wp-content/uploads/IEEE-Reference-

Guide.pdf\%0Ahttp://wwwlib.murdoch.edu.au/find/citation/ieee.html\%0Ahttps://doi.or g/10.1016/j.cie.2019.07.022\%0Ahttps://github.com/ethereum/wiki/wiki/WhitePaper\%0Ahttps://tore.tuhh.de/hand

Nurgiansah, T. H. (2020). Filsafat Pendidikan. In Banyumas: CV Pena Persada.

Nurgiansah, T. H. (2021). Pendidikan Pancasila. In Solok: CV Mitra Cendekia Media.

Pasar Tradisional: Pengertian, Ciri-Ciri, Kelebihan dan Kekurangannya. https://ekonomi.bunghatta.ac.id/index.php/id/artikel/331-pasar-tradisionalpengertian-ciri-ciri-kelebihan-dan-kekurangannya

Rahmat, Bintang. (2019). Belanja Online vs. Pasar Konvensional. http://www.harnas.co/2019/12/09/belanja-online-vs-pasar-konvensional

Welianto, Ari. (2020). Manusia sebagai Makhluk Ekonomi dan Cirinya. https://www.kompas.com/skola/read/2020/07/07/153000069/manusia-sebagaimakhluk-ekonomi-dan-cirinya 